\title{
THE EMERGENCE OF ESPORTS NUTRITION: A REVIEW
}

\author{
Fernando J. Ribeiro, 1, 2, A, B, D Victor M. Viana, 1, 3, 4, D Nuno P. Borges, 1, 4, D \\ Vitor H. Teixeira, ${ }^{1,5,}$ A, D \\ ${ }^{1}$ Faculty of Nutrition and Food Science of the University of Porto (FCNAUP), Porto, Portugal \\ ${ }^{2}$ Faculty of Sciences of the University of Porto (FCUP), Porto, Portugal \\ ${ }^{3}$ Centro Hospitalar Universitário S. João, Porto, Portugal \\ ${ }^{4}$ CINTESIS, Porto, Portugal \\ ${ }^{5}$ Research Centre in Physical Activity, Health and Leisure (CIAFEL), Porto, Portugal

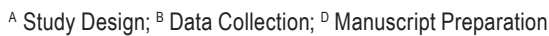 \\ Address for correspondence: \\ Fernando J. Ribeiro \\ Rua da Certaínha, n. ${ }^{0}$ 143, 4630-247 Marco de Canaveses, Portugal \\ E-mail: fernandoribeiro1393@gmail.com
}

\begin{abstract}
Ahstragt Peak cognitive performance is of paramount importance for the sports and competitive activities that depend on a high level of cognitive performance, such as eSports. The popularity of eSports has increased rapidly in recent years and will probably continue to rise in the forthcoming years. Above all, eSports practitioners require higher levels of cognitive abilities and motor skills for optimal performance and may benefit from adequate body composition and proper nutrition, as happens with more traditional athletes. However, there is a noticeable shortage of scientific knowledge in this area, including in nutritional-related aspects. Therefore, the objective of this non-systematic review is to summarize the nutritional strategies that may enhance health, cognitive performance, decrease reaction time and minimize fatigue. This information may be relevant for eSports competitors and set a base for further investigations, which could ultimately lead to the establishment of nutritional recommendations specific for this competitive population.
\end{abstract}

Key Worlds esports, nutrition, eSports nutrition, video games, cognitive performance

\section{Introduction}

Traditionally, sports nutrition has focused on promoting an optimum level of physical fitness particularly for athletes of more physically intense sports, such as the marathon, football, weightlifting, etc. (Kerksick et al., 2018). However, sport is not limited to these modalities. There are other sports and competitive activities that depend mainly on another type of skills, like a high level of cognitive capacity, high-speed response, accuracy and resistance to mental fatigue, such as billiards, darts, motorsports, drone racing, chess, and eSports (Campbell, Toth, Moran, Kowal, Exton, 2018).

eSports involve video game competitions with other players. Some examples of eSports games include League of Legends, Dota 2, Starcraft II, Counter-Strike: Global Offensive, and the FIFA series (Hamari, Sjöblom, 2017). 
While it is debatable if eSports are considered a true sport or not, its popularity has been growing tremendously, and it is estimated that by the end of the year 2018, it may have reached a total of 380 million fans and $\$ 906$ million in incomes (Hallmann, Giel, 2018).

The practice of eSports may provide benefits in various cognitive domains, including refined attention, memory, plasticity, spatial reasoning and problem-solving, among others (Taylor, Elam, 2018). It may also motivate students to reduce school absenteeism and improve their grades, and, as it is practiced in teams, it could also improve soft skills that are desired by universities and employers, such as teamwork, communication skills and problem-solving in high-pressure contexts (Rothwell, Shaffer, 2019).

The average age of eSports professional players maybe around 21-25 years (ESPN, 2017, acessed: 22.01.2020) and their careers are usually very brief, lasting until their mid-twenties, an age from which their speed of responsive action starts decreasing and younger competitors may be in advantage (Hallmann, Giel, 2018). The scientific literature mentions various cognitive domains that seem to be of the utmost importance in the competitive practice of video games, namely: fine cognitive motor skills, including aiming and manual dexterity (Reeves, Brown, Laurier, 2009), cognitive motor speed, including reaction time, speed of action and actions perminute (Huang, Yan, Cheung, Nagappan, Zimmermann, 2017; Reeves et al., 2009), fluid intelligence, memory (Kokkinakis, Cowling, Drachen, Wade, 2017), visuospatial attention (Han, Lyoo, Renshaw, 2012), concentration (Cottrell, McMillen, Harris, 2019), resistance to mental fatigue (Thomas, Rothschild, Earnest, Blaisdell, 2019), multitasking, management and organization (Huang et al., 2017).

Nonetheless, it seems that most competitors do not recognize the cognitive and physiological demands of competitive eSports, and fail to adhere to healthy dietary patterns, not preparing themselves for competition in a professional manner (Schütz, 2016). As in most sports, and as the level of demand rises, a progressive increase in demand for strategies to improve performance is expected, and there are already companies dedicated to providing personalized programs, including nutritional plans (Himmelstein, Liu, Shapiro, 2017). However, there is a noticeable shortage of scientific knowledge in this area, including in the field of nutritional science.

The objective of this review is to summarize how nutritional status and dietary strategies can influence health, cognitive performance, decrease reaction time and minimize fatigue. While the information here summarized may be relevant for eSports competitors, it may have a higher favorable influence for typical adolescents and young adults, as high-level eSports players may already be operating close to the limit of human cognitive ability, leaving little room for performance improvement (Bernard, Louise, Louise, 2018).

\section{Methods}

This article is a non-systematic review and the information here resumed was collected through research on Google Scholar, PubMed, and Web of Science. The searches included the following keywords: "esports", "cognition", "nutrition", "diet", "breakfast”, "lunch", "snack", "evening meal”, "protein”. "carbohydrates", "glucose”, "fat”, "saturated fats", "polyunsaturated fats", "vitamins", "minerals", "hydration”, "alcohol”, "coffee”, "caffeine”, "BMl”, "overweight”, "obesity", and "weight loss". The information considered relevant was included in this review. In addition, published books on nutrition and cognition were also consulted for retrieval of additional information and references. 


\section{Diet-pelated aspects influence on cognition \\ Diet quality}

Diet quality may impact cognitive capacities, including learning and memory of the immature and adult brain (Reichelt, Westbrook, Morris, 2017). Poor eating habits are associated with decreased performance in various cognitive domains (Wright, Gerassimakis, Bygrave, Waldstein, 2017), which may be partially explained by ethanol neurotoxicity (Brust, 2010), increased brain inflammation promoted by high fat (Pistell et al., 2010) and high sugar diets (Yeomans, 2017). The western pattern diet, which is typically high in refined sugars and cereals, sodium, saturated fats and alcohol (Statovci, Aguilera, MacSharry, Melgar, 2017), may predispose to obesity, is linked to an overall decrease in cognitive function, and may have a negative influence in the hippocampus, which is implicated in memorization and learning (Morris, Beilharz, Maniam, Reichelt, Westbrook, 2015).

On the other hand, a healthier diet correlates with optimum mental performance (Kim, Kang, 2017). The Mediterranean diet, which is composed mainly by significant amounts of whole grains, legumes, vegetables, fruit and a modest amount of fish, dairy and olive oil, may decrease the risk of cognitive impairments (RaddVagenas Duffy, Naismith, Brew, Flood, Fiatarone Singh, 2018).

\section{Meal patterns}

Meal timing, size, and composition also have the potential to affect cognitive performance (Dye, Lluch, Blundell, 2000; Leigh Gibson, Green, 2002; Prasad, Lieberman, Kanarek, 2005).

Moreover, the ingestion of a meal with a nutritional composition different to the one that is usually eaten seems to worsen the mood and energy ratings (Cunliffe, Obeid, Powell-Tuck, 1997).

The frequent omission of meals, especially breakfast, in young adults, is correlated with inferior diet quality, reduced intake of micronutrients, greater BMI and risk of abdominal adiposity, increased insulin resistance (Pendergast, Livingstone, Worsley, McNaughton, 2016), poorer sleep (Tanaka et al., 2002), fatigue, decreased attention, and inferior academic performance (Ackuaku-Dogbe, Abaidoo, 2014).

Breakfast intake enhances cognitive aspects linked to attention, executive function, memory (Adolphus, Lawton, Champ, Dye, 2016), test scores (Rampersaud, Pereira, Girard, Adams, Metzl, 2005), and improves the capacity to cope with cognitive workload (Sihvola et al., 2013).

There is some evidence that lunch is a major contributor for the post-prandial dip in performance, and leads to a decline in some aspects of cognitive performance, including in discrimination efficiency, sustained attention (Smith,Miles, 1986), and increased response time (Lloyd, Green, Rogers, 1994). These detrimental effects may be modulated by personality type (Craig, Baer, Diekmann, 1981) and meal size, with biggest decrements being observed after the ingestion of a big (922-1,380 Kcal) versus a light lunch (260-305 Kcal) (Craig, Richardson, 1989; Reyner, Wells, Mortlock, Horne, 2012). The ingestion of a lunch containing high amounts of fat or carbohydrates decreases alertness and cognitive efficiency (Lloyd et al., 1994).

In a study involving university students as volunteers, those who had an evening meal felt more energetic, more attentive, more competent and achieved a better performance in a logical reasoning test than those who didn't (Smith, Maben, Brockman, 1994). On the other hand, the ingestion of a big supper (30\% of daily total energy intake) at late night increased sleepiness (Gupta et al., 2019), decreased driving performance and vigilant attention 
(Gupta et al., 2019; Gupta et al., 2017), while the ingestion of a light meal (10\% of $24 \mathrm{~h}$ energy intake) led to improved performance in those parameters (Gupta et al., 2019).

\section{Hydration}

It is estimated that $54.5 \%$ of the USA children and adolescents (Kenney, Long, Cradock, Gortmaker, 2015) and $15,8 \%$ of the adults (20-29 years) are dehydrated and $40 \%$ have borderline blood plasma hypertonicity (295 to $300 \mathrm{mmol} / \mathrm{L})$ (Stookey, 2005).

Water accounts for $75 \%$ of brain mass (Zhang, Du, Zhang, Ma, 2019) and hydration status may be one of the main variables that affect the performance of eSports practitioners since there is reasonably consistent evidence that a dehydration level greater than $2 \%$ of body mass decreases cognitive performance (Adan, 2012; Riebl, Davy, 2013) decreases alertness, mood and increases fatigue (Benton, Young, 2015). Seemingly, a greater level of dehydration correlates with greater decreases in cognitive performance and mood (Pross et al., 2013), while water consumption can improve these parameters (Masento, Golightly, Field, Butler, van Reekum, 2014).

Moreover, some studies suggest that a dehydration level of $1-2 \%$ is enough to diminish cognitive performance (Riebl, Davy, 2013), and a more recent study found that a dehydration level of only $0.22 \%$ had a negative influence on memory and attention (Benton, Jenkins, Watkins, Young, 2016).

Indeed, the mere sensation of thirst may negatively affect memory and attention (Benton et al., 2016; Benton, Young, 2015) possibly by diverting some attention from cognitive performance (Benton, Young, 2015), and it was observed that the consumption of water favors mental performance in thirsty young adults, although it impaired it in those who were not thirsty (Rogers, Kainth, Smit, 2001).

Even if a moderate level of dehydration doesn't decrease cognitive test performance in adolescents and healthy adults, it may require more brainwork to reach a similar cognitive output as in a hydrated condition (Barulli, Stern, 2013; Kempton et al., 2011; Stern, 2017), and these individuals also exhibit lower mental clarity, well-being and greater fatigue (Kempton et al., 2011).

The daily amount of water necessary to maintain euhydration varies between individuals and must be adjusted to environmental conditions. The European Food Safety Agency (EFSA) has set an adequate total water intake value of 2,5L/day for males and 2,0L/day for females (EFSA, 2017).

\section{Nutrients}

Glucose. Notwithstanding constituting just $\sim 2 \%$ of an adult individual's body mass, the energy expenditure of the brain represents $\sim 20 \%$ of the body total expenditure (Herculano-Houzel, 2011). Because its energy reserves are limited, brain depends on continued delivery of glucose, its main fuel substrate (Murray, Rosenbloom, 2018) except during long periods of fasting, in which it oxidizes ketone bodies (Morris, 2005). In fasting and resting conditions, approximately $60 \%$ of blood glucose is metabolized by the brain (Wasserman, 2009), totalizing around $130 \mathrm{~g}$ about glucose/day (Lupton, Brooks, Butte, Caballero, Flatt, Fried, 2005).

In cognitively demanding scenarios, brain glucose consumption can increase by up to $12 \%$ (Madsen et al., 1995), and blood glucose levels may drop by as much as 10\% (Fairclough, Houston, 2004; Gailliot et al., 2007; Scholey, Harper, Kennedy, 2001; Scholey, Laing, Kennedy, 2006). It has been shown that playing Tetris consumes a significant quantity of glucose (Haier, Siegel, Tang, Abel, Buchsbaum, 1992) and decreases blood glucose levels (Lange, Seer, Rapior, Rose, Eggert, 2014). In this context, the consumption of glucose may increase the availability 
of this nutrient and support the brain areas involved in the heightened workload and ultimately increase cognitive performance (Smith, Riby, Eekelen, Foster, 2011).

The potential mechanisms behind glucose cognitive enhancement effects through a) increased acetylcholine production, whose synthesis depends upon glucose (Messier, 2004); b) raised insulin levels, which may promote hippocampus glucose utilization (Craft, Murphy, Wemstrom, 1994); c) rewarding pathways upon activation of glucose-sensitive receptors present in the mouth (Hagger, Chatzisarantis, 2013); d) interplay with dopamine, serotonin, and opiates (Riby, 2004).

The positive effects of glucose administration on cognitive performance have been supported by the results of a meta-analysis (Riby, 2004), with larger effects on episodic memory, and possible benefits on sustained attention and vigilance (Bernard et al., 2018). The cognitive enhancements may be visible up to 20 min after its ingestion (Jones, Sunram-Lea, Wesnes, 2012) and glucose blood levels may start to decline after around $30 \mathrm{~min}$, dropping to basal levels in approximately 2 hours (Benton, Parker, Donohoe, 1996). The nootropics effects of glucose seem more noticeable on prolonged and cognitively demanding tasks and in fasting conditions (Riby, 2004). This may explain why most interventions were performed at breakfast time (Hoyland, Lawton, Dye, 2008). These nootropic effects may be short-lived, as impairments in working memory have been detected 60 min after the administration of $25 \mathrm{~g}$ of glucose, possible due to a subsequent decrease in plasma glucose levels, secondary to increased insulin levels (Jones et al., 2012).

It may not be necessary to ingest carbohydrates through a pure glucose solution to potentiate cognition. The ingestion of a dietary source of carbohydrates (breakfast cereals) at early morning also improves spatial memory (Smith, Clark, Gallagher, 1999). Moreover, the regular ingestion of sugary drinks, including energy drinks and sports drinks, should be discouraged due to its association with increased inflammation, weight gain and oral health problems (Aeberli et al., 2011; Malik, Pan, Willett, Hu, 2013; Hardy, Bell, Bauman, Mihrshahi, 2018).

It should be noted that practicing eSports for many hours a day and during various months may lower or block the cognitive benefits associated with glucose intake. Playing Tetris daily for 4-8 weeks result in a decrease in cerebral glucose expenditure, despite a concomitant $>7$-fold increase in performance (Haier et al., 1992).

Lipids. Lipids account for 50-60\% of adult brain's dry weight (Sastry, 1985) and it was found that alterations in the lipid constituents of neurons membrane may affect neurotransmission by modulating the activity of ion channels, receptors, enzymes and ion channels wrapped or involved with the membrane phospholipids (Prasad et al., 2005). In humans, high-fat diets have been documented to modify the brain metabolism of glucose, causing the electroconvulsive threshold to rise (Appleton, DeVivo, 1974), and the consumption of fatty foods has been robustly correlated with an increase in reaction time (Phillimore, 1988).

The type of fat may also influence cognition. The ingestion of higher amounts of unsaturated fatty acids has been correlated with optimized cognitive health in comparison with saturated fatty acids (Cao et al., 2019), while the ingestion of trans fatty acids is strongly linked with the worsening of word recall ability (Golomb, Bui, 2015). Trans fatty acids, which are produced in industrial installations (Stender, Astrup, Dyerberg, 2008), are associated to increased oxidative stress (Tomey et al., 2007), negative repercussions on blood lipids, metabolic processes, decreased glucose tolerance, general body inflammation, disrupted endothelial function, visceral adiposity, increased BMI, worsening of cardiac and general health (Mozaffarian, Aro, Willett, 2009), which may impair cognition (Atzmon et al., 2002; Eggermont et al., 2012; Geroldi et al., 2005; Isaac et al., 2011; Messerotti, Benvenuti, Zanatta, Valfre, Polesel, Palomba, 2012; van Exel et al., 2003). 
Additionally, dietary trans fats decrease the availability of the long chain omega-3 fatty acids EPA and DHA, which are anti-inflammatory (Kaur, Chugh, Gupta, 2014), important to brain health and have been associated with a more favorable cognitive function (Lim, Gammack, Van Niekerk, Dangour, 2006; Robinson, ljioma, Harris, 2010).

According to EFSA, for adults, the ingestion of total fat should represent $20-35 \%$ of total energy intake, the adequate intake of EPA + DHA is $250 \mathrm{mg} /$ day, and the intake of saturated fat and trans fats should be as low as possible (EFSA, 2017).

Unlike glucose, the effects of acute consumption of pure fat and protein on cognition have been scarcely studied, with contradictory results. These inconsistencies may have been due to different methodologies applied in these studies. Additional investigations must be conducted before any conclusions can be drawn (Bachlechner et al., 2017; Jones et al., 2012).

Protein. The ingestion of adequate amounts of protein is also necessary for optimum brain development and functioning. With a protein content of approximately $10 \%$ (Banay-Schwartz, Kenessey, DeGuzman, Lajtha, Palkovits, 1992), the brain has a daily turnover rate of $3-4 \%$, superior to that of skeletal muscle mass (1-2\%) (Smeets et al., 2018). The central nervous systems also uses amino acids as neurotransmitters or as substrates for the synthesis of neurotransmitters and neuromodulators (Chertoff, 2015). The production of the neurotransmitters serotonin and catecholamines requires tryptophan and tyrosine as substrates, respectively, and its synthesis rate is influenced by the blood availability of these amino acids and, consequently, by the ingestion of protein (Fernstrom, Fernstrom, 2007).

It has been observed that the ingestion of a larger proportion of carbohydrates relative to protein raises tryptophan levels by elevating insulin levels, which promotes the uptake of the large neutral amino acids (LNAA) valine, leucine, and isoleucine by muscle tissues, thus dropping their blood levels, while tryptophan levels remain relatively unaltered. As tryptophan competes with these branched chain amino acids for the same transporter through the blood-brain barrier (BBB), the rate of transport of tryptophan through the BBB increases, as well as the brain availability of this amino acid, thus increasing serotonin production, a neurotransmitter that exerts sedating effects and consequently slows motor performance (Lieberman, 1999; van de Rest, van der Zwaluw, de Groot, 2013).

In general, dietary protein sources contains higher proportions of tyrosine in comparison with tryptophan. Being a LNAA, tyrosine competes for transport through the BBB with tryptophan and other LNAAs. As the proportion of protein to carbohydrates of a given meal increases, greater decreases in tryptophan levels are observed and, consequently, the brain synthesis of serotonin also decreases (Lieberman, 1999; van de Rest et al., 2013).

Acute high-stress conditions may decrease brain tyrosine levels due to heightened catecholamines synthesis triggered by an increased fire rate of central catecholaminergic neurons. In these cases, the ingestion of a proteinrich food increases blood tyrosine levels, favors its transport through the BBB, and boosts brain catecholamines synthesis, which may increase alertness and enhance cognition (Lieberman, 1999; van de Rest et al., 2013). Arguably, the lifestyle of eSports professional players may be considered stressful, especially in periods congested with important competitions (Pereira, Brito, Figueiredo, Verhagen, 2019).

In 2010 Jakobsen et al. applied a high protein diet $(3.0 \mathrm{~g} \mathrm{~kg} / \mathrm{body}$ weight) to a group of healthy young male college students (19-31 years), for 3 weeks, while another group followed a usual protein diet (1.5 g kg). These authors observed a significantly reduction in the reaction time in the high protein group, in comparison with the usual protein diet group, and attributed these effects mainly to increased levels of tyrosine, but also to raised 
phenylalanine and BCAA concentration in the high protein group (Jakobsen, Kondrup, Zellner, Tetens, Roth, 2011). However, there is clearly a need for further investigations on this topic. Moreover, the amount ingested by the high protein diet largely surpassed the population reference intake value of $0.83 \mathrm{~g} / \mathrm{kg}$ proposed by EFSA (EFSA, 2017).

Micronutrients. The brain energy metabolism is also dependent on an adequate supply of vitamins and minerals (Kennedy et al., 2016). Low brain magnesium levels appear to decrease serotonin levels and promote depressive states (Eby, Eby, 2010), which may decrease performance in cognitive tasks, possibly due to a reduced capacity to allocate cognitive resources to challenging tasks (Jones, Siegle, Muelly, Haggerty, Ghinassi, 2010). Due to its key role in myoglobin, cytochromes, and many other cellular proteins and enzymes (DeLoughery, 2017), iron deficiency has been strongly associated with fatigue (Brunner, Wuillemin, 2010) and decreased mental performance in children (Lozoff, Beard, Connor, Barbara, Georgieff, Schallert, 2006) and young adults (Scott,Murray-Kolb, 2016). lodine is necessary for the endogenous production of two hormones in the thyroid (triiodothyronine and thyroxine), which influence human development and growth, including the central nervous system (Zimmermann, 2009). lodine deficiency may cause a number of negative health consequences, including impaired cognition capacity (Zimmermann, 2009). Zinc plays a key role in controlling the expression of genes and in normal synaptic signaling processes (Trumbo, Yates, Schlicker, Poos, 2001). Vitamin D deficiency might have negatives effects on the brain because it also has vitamin D receptors (Garcion, Wion-Barbot, Montero-Menei, Berger, Wion, 2002) and some studies suggest that hypovitaminosis $D$ is associated with a lower cognition performance in adults (Goodwill, Szoeke, 2017).

Caffeine. Caffeine is considered the main constituent of coffee that provides cognitive facilitation effects (Haskell-Ramsay, Jackson, Forster, Dodd, Bowerbank, Kennedy, 2018). A dosage of $100 \mathrm{ml}$ of coffee, extracted by the drip method, contains 60-100 mg of caffeine, an amount found sufficient to improve reaction time, alertness, vigilance, and attention ( $[0,5$ to $4 \mathrm{mg} / \mathrm{kg}$ ) (McLellan, Caldwell, Lieberman, 2016). This value is below the EFSA established safe upper limit for acute caffeine ingestion ( $3 \mathrm{mg} / \mathrm{kg}$ ) (EFSA Panel on Dietetic Products \& Allergies, 2015). Nonetheless, coffee contains other components, such as chlorogenic acids, that may also exert positive mood and cognitive effects (Camfield et al., 2013). One study found that the ingestion of decaffeinated coffee improved alertness in young healthy adults (Haskell-Ramsay et al., 2018). In another investigation, the mere act of smelling coffee improved performance on an analytical reasoning task, an effect that may be attributed to the placebo effect (Madzharov, Ye, Morrin, Block, 2018).

Alcohol. Binge and heavy alcohol drinking during adolescence, a time when the brain is still maturing, is associated with significant negative brain and behavioral changes, inferior academic performance, retardation of white matter maturation, and volume reductions of specific brain areas, such as the cerebellar region and the frontal lobe (Cservenka, Brumback, 2017).

\section{Cognition and weight status}

Obesity may induce insulin resistance, promote inflammation, increase oxidative stress, and lead to endothelial dysfunction (Montero, Walther, Perez-Martin, Roche, Vinet, 2012), which can be harmful to the brain, and correlates with cortical thinning of specific brain regions, diminished integrity of white matter and reduced nerve conduction velocity in adolescents (Medic et al., 2016; Sweat, Yates, Migliaccio, Convit, 2017; Yau, Kang, Javier, Convit, 2014) and adults (Majumdar, Chaudhuri, Ghar, Rahaman, Hai, 2017; Stanek et al., 2011; Xu, Li, Lin, Sinha, Potenza, 2013). Compared with their lean counterparts, obese adolescents perform worst in various domains of cognition, such as 
arithmetic, working memory, spelling, mental flexibility, attention, executive functioning, cognitive processing speed, visuospatial performance, and motor skills (Liang, Matheson, Kaye, Boutelle, 2014; Sweat et al., 2017; Yau et al., 2014).

A significant percentage of esports practitioners may be overweight. In a survey conducted in Germany, involving 1,066 esports players from 18 to 38 years old, the average BMI was $24.6( \pm 4.8)$ and that only $51.9 \%$ of the sample had a normal weight, while the mean value for the population of Germany with the same age is $59.9-72.3 \%$. Moreover, time spent playing video games was positively associated to BMI and self-reported health status (Rudolf, Bickmann, Froböse, Tholl, Wechsler, Grieben, 2020).

If obesity is linked to decreased cognitive performance, it is reasonable to theorize that weight loss could improve cognitive performance in obese. Indeed, intentional weight loss seems to enhance several aspects of cognition in overweight and obese adults, such as executive function, attention, memory, and language (Veronese et al., 2017), although some works only found cognitive benefits in obese and not in overweight individuals (Siervo et al., 2011).

Weight loss requires a negative energy balance, which has been associated with functional cognitive deficits in self-reported dieters (Green, Rogers, 1995, 1998; Kemps, Tiggemann, 2005; Kemps, Tiggemann, Marshall, 2005; Vreugdenburg, Bryan, Kemps, 2003), that seems to be more concerned with esthetics ( Green, Elliman, Rogers, 1997; Green Rogers, 1998; Kemps Tiggemann, 2005; Kemps et al., 2005; Shaw,Tiggemann, 2004; Vreugdenburg et al., 2003). Such concerns can deviate cognitive resources for trivial cognitive tasks, thus diminishing the total cognitive resources available to other mental tasks (Green et al., 1997; Green, Rogers, Elliman, Gatenby, 1994; Sebastian, Williamson, Blouin, 1996). However, such association is missing or minimized when weight loss is reported or energy restriction is applied through clinical intervention (Bryan, Tiggemann, 2001; Green, Elliman, Rogers, 1995; Kretsch, Green, Fong, Elliman, Johnson, 1997; Landers, Arent, Lutz, 2001; Martin et al., 2007).

On the other hand, a too low BMI (i.e. anorexia nervosa) may impair cognitive flexibility and working memory. Weight recovery seems to restore these cognitive domains (Olivo, Gaudio, Schiöth, 2019). Chronic malnutrition undoubtedly hinders cognitive development and performance (Dauncey Bicknell, 1999; Kretchmer, Beard, Carlson, 1996).

\section{Conclusions}

To our knowledge, to date, no studies have evaluated the effects of dietary strategies on the cognitive performance of eSports competitors. However, there is a relatively great amount of evidence regarding nutritional strategies that may simultaneously benefit health and cognition, which may also be useful to eSports players:

1. Maintain an adequate weight for height.

2. Follow a low $\mathrm{GI}$, high quality, and nutritious diet.

3. Limit the intake of fat to (20-25 total energy) an avoid saturated and trans fat.

4. Avoid and correct possible vitamin and mineral deficits.

5. Maintain a regular dietary pattern and do not skip breakfast.

6. A light meal at lunch may minimize the detrimental effects of post-lunch dip on cognition.

7. Avoid drinking alcoholic beverages.

8. Maintain an adequate hydration state, especially before competitions.

9. Consider the sensible ingestion of coffee before competitions. 
Considering the currently available literature, it is not yet possible to establish specific recommendations for eSports competitors, but the information here presented may help to set a basis and identify the most viable topics which warrant further investigation. As this new world of eSports involves an increasing number of individuals over time, it is urgent to carry out further research in this area, which may ultimately lead to the establishment of nutritional and supplementation recommendations that may promote health and optimize cognitive performance.

\section{References}

Ackuaku-Dogbe, E.M., Abaidoo, B. (2014). Breakfast eating habits among medical students. Ghana medical journal, 48 (2), 66-70.

Adan, A. (2012). Cognitive performance and dehydration. J Am Coll Nutr, 31 (2), 71-78. DOI: 10.1080/07315724.2012.10720011.

Adolphus, K., Lawton, C.L., Champ, C.L., Dye, L. (2016). The Effects of Breakfast and Breakfast Composition on Cognition in Children and Adolescents: A Systematic Review. Adv Nutr, 7 (3), 590s-612s. DOI: 10.3945/an.115.010256.

Aeberli, I., Gerber, P.A., Hochuli, M., Kohler, S., Haile, S.R., Gouni-Berthold, I., Berthold, H.K, Spinas, G.A, Berneis, K. (2011). How to moderate sugar-sweetened beverage consumption impairs glucose and lipid metabolism and promotes inflammation in healthy young men: a randomized controlled trial. Am J Clin Nutr, 94 (2), 479-485. DOI: 10.3945/ajcn.111.013540.

Appleton, D.B., DeVivo, D.C. (1974). An animal model for the ketogenic diet. Epilepsia, 15 (2), 211-227. DOI: 10.1111/j.1528-1157.1974. tb04943.x.

Atzmon, G., Gabriely, I., Greiner, W., Davidson, D., Schechter, C., Barzilai, N. (2002). Plasma HDL levels highly correlate with cognitive function in exceptional longevity. J Gerontol A Biol Sci Med Sci, 57 (11), M712-715. DOI: 10.1093/gerona/57.11.m712.

Bachlechner, S., Denzer-Lippmann, M.Y., Wielopolski, J., Fischer, M., Buettner, A., Doerfler, A., Schöfl, C., Münch, G., Kornhuber, J., Thürauf, N. (2017). The Effects of Different Isocaloric Oral Nutrient Solutions on Psychophysical, Metabolic, Cognitive, and Olfactory Function in Young Male Subjects. Front Psychol, 8, 1988. DOI: 10.3389/fpsyg.2017.01988.

Banay-Schwartz, M., Kenessey, A., DeGuzman, T., Lajtha, A., Palkovits, M. (1992). Protein content of various regions of rat brain and adult and aging human brain. AGE, 15 (2), 51-54. DOI: 10.1007/BF02435024.

Barulli, D., Stern, Y. (2013). Efficiency, capacity, compensation, maintenance, plasticity: emerging concepts in cognitive reserve. Trends Cogn Sci, 17 (10), 502-509. DOI: 10.1016/j.tics.2013.08.012.

Benton, D., Jenkins, K.T., Watkins, H.T., Young, H.A. (2016). Minor degree of hypohydration adversely influences cognition: a mediator analysis. Am J Clin Nutr, 104 (3), 603-612. DOI: 10.3945/ajcn.116.132605.

Benton, D., Parker, P.Y., Donohoe, R.T. (1996). The supply of glucose to the brain and cognitive functioning. J Biosoc Sci, 28 (4), 463-479. DOI: $10.1017 / \mathrm{s} 0021932000022537$.

Benton, D., Young, H.A. (2015). Do small differences in hydration status affect mood and mental performance? Nutr Rev, 73 Suppl 2 , 83-96. DOI: 10.1093/nutrit/nuv045.

Bernard, B.N., Louise, L.C., Louise, D. (2018). The Effects of Carbohydrates, in Isolation and Combined with Caffeine, on Cognitive Performance and Mood-Current Evidence and Future Directions. Nutrients, 10 (2), 192. DOI: 10.3390/nu10020192.

Brunner, C., Wuillemin, W.A. (2010). Iron deficiency and iron deficiency anemia - symptoms and therapy. Ther Umsch, 67 (5), 219-223. DOI: $10.1024 / 0040-5930 / a 000040$.

Brust, J.C.M. (2010). Ethanol and cognition: indirect effects, neurotoxicity and neuroprotection: a review. International journal of environmental research and public health, 7 (4), 1540-1557. DOI: 10.3390/ijerph7041540.

Bryan, J., Tiggemann, M. (2001). The effect of weight-loss dieting on cognitive performance and psychological well-being in overweight women. Appetite, 36 (2), 147-156. DOI: 10.1006/appe.2000.0389.

Camfield, D.A., Silber, B.Y., Scholey, A.B., Nolidin, K., Goh, A., Stough, C. (2013). A randomised placebo-controlled trial to differentiate the acute cognitive and mood effects of chlorogenic acid from decaffeinated coffee. PLoS One, 8 (12), e82897. DOI: 10.1371/ journal.pone.0082897.

Campbell, M.J., Toth, A.J., Moran, A.P., Kowal, M., Exton, C. (2018). eSports: A new window on neurocognitive expertise? Prog Brain Res, 240, 161-174. DOI: 10.1016/bs.pbr.2018.09.006.

Cao, G.Y., Li, M., Han, L., Tayie, F., Yao, S. S., Huang, Z., ..., Xu, B. (2019). Dietary Fat Intake and Cognitive Function among Older Populations: A Systematic Review and Meta-Analysis. J Prev Alzheimers Dis, 6 (3), 204-211. DOI: 10.14283/jpad.2019.9.

Chertoff, M. (2015). Protein malnutrition and brain development. Brain Disord. Ther, 4 (3). 
Cottrell, C., McMillen, N., Harris, B. S. (2019). Sport psychology in a virtual world: Considerations for practitioners working in eSports. Journal of Sport Psychology in Action, 10 (2), 73-81. DOI: 10.1080/21520704.2018.1518280.

Craft, S., Murphy, C., Wemstrom, J. (1994). Glucose effects on complex memory and nonmemory tasks: The influence of age, sex, and glucoregulatory response. Psychobiology, 22 (2), 95-105. DOI: 10.3758/BF03327086.

Craig, A., Baer, K., Diekmann, A. (1981). The effects of lunch on sensory-perceptual functioning in man. International Archives of Occupational and Environmental Health, 49 (2), 105-114.

Craig, A., Richardson, E. (1989). Effects of experimental and habitual lunch-size on performance, arousal, hunger and mood. Int Arch Occup Environ Health, 61 (5), 313-319. DOI: 10.1007/bf00409386.

Cservenka, A., Brumback, T. (2017). The Burden of Binge and Heavy Drinking on the Brain: Effects on Adolescent and Young Adult Neural Structure and Function. Front Psychol, 8, 1111. DOI: 10.3389/fpsyg.2017.01111.

Cunliffe, A., Obeid, O.A., Powell-Tuck, J. (1997). Post-prandial changes in measures of fatigue: effect of a mixed or a pure carbohydrate or pure fat meal. Eur J Clin Nutr, 51 (12), 831-838. DOI: 10.1038/sj.ejcn.1600496.

Dauncey, M.J., Bicknell, R.J. (1999). Nutrition and neurodevelopment: mechanisms of developmental dysfunction and disease in later life. Nutr Res Rev, 12 (2), 231-253. DOI: 10.1079/095442299108728947.

DeLoughery, T.G. (2017). Iron Deficiency Anemia. Med Clin North Am, 101 (2), 319-332. DOI: 10.1016/j.mcna.2016.09.004.

Dye, L., Lluch, A., Blundell, J.E. (2000). Macronutrients and mental performance. Nutrition, 16 (10), 1021-1034. DOI: 10.1016/ s0899-9007(00)00450-0.

Eby, G.A., Eby, K.L. (2010). Magnesium for treatment-resistant depression: a review and hypothesis. Med Hypotheses, 74 (4), 649-660. DOI: 10.1016/j.mehy.2009.10.051.

EFSA (2017). Dietary reference values for nutrients summary report (2397-8325). Retrieved from

EFSA Panel on Dietetic Products \& Allergies. (2015). Scientific Opinion on the safety of caffeine. EFSA Journal, 13 (5), 4102.

Eggermont, L.H., de Boer, K., Muller, M., Jaschke, A.C., Kamp, O., Scherder, E.J. (2012). Cardiac disease and cognitive impairment: a systematic review. Heart, 98 (18), 1334-1340. DOI: 10.1136/heartjnl-2012-301682.

ESPN (2017). Average age in esports vs. major sports. Retrieved from: https://www.espn.com/esports/story/_lid/20733853/theaverage-age-esports-versus-nfl-nba-mlb-nhl (22.01.2020).

Fairclough, S.H., Houston, K. (2004). A metabolic measure of mental effort. Biol Psychol, 66 (2), 177-190. DOI: 10.1016/j. biopsycho.2003.10.001.

Fernstrom, J.D., Fernstrom, M.H. (2007). Tyrosine, phenylalanine, and catecholamine synthesis and function in the brain. J Nutr, 137 (6 Suppl 1), 1539S-1547S; discussion 1548S. DOI: 10.1093/jn/137.6.1539S.

Gailliot, M.T., Baumeister, R F., DeWall, C.N., Maner, J.K., Plant, E.A., Tice, D.M., Brewer, L.E., Schmeichel, B.J. (2007). Self-control relies on glucose as a limited energy source: willpower is more than a metaphor. J Pers Soc Psychol, 92 (2), 325-336. DOI: 10.1037/0022-3514.92.2.325.

Garcion, E., Wion-Barbot, N., Montero-Menei, C.N., Berger, F., Wion, D. (2002). New clues about vitamin D functions in the nervous system. Trends Endocrinol Metab, 13 (3), 100-105.

Geroldi, C., Frisoni, G.B., Paolisso, G., Bandinelli, S., Lamponi, M., Abbatecola, A.M., Zanetti, O., Guralnik, J.M., Ferrucci, L. (2005). Insulin resistance in cognitive impairment: the InCHIANTI study. Arch Neurol, 62 (7), 1067-1072. DOI: 10.1001/archneur.62.7.1067.

Golomb, B.A., Bui, A.K. (2015). A Fat to Forget: Trans Fat Consumption and Memory. PLoS One, 10 (6), e0128129-e0128129. DOI: 10.1371/journal. pone.0128129.

Goodwill, A.M., Szoeke, C. (2017). A Systematic Review and Meta-Analysis of The Effect of Low Vitamin D on Cognition. J Am Geriatr Soc, 65 (10), 2161-2168. DOI: 10.1111/jgs.15012.

Green, M.W., Elliman, N.A., Rogers, P.J. (1995). Lack of effect of short-term fasting on cognitive function. Journal of psychiatric research, 29 (3), 245-253. DOI: 10.1016/0022-3956(95)00009-t.

Green, M.W., Elliman, N.A., Rogers, P.J. (1997). Impaired cognitive processing in dieters: Failure of attention focus or resource capacity limitation? British Journal of Health Psychology, (3), 259-267.

Green, M.W., Rogers, P.J. (1995). Impaired cognitive functioning during spontaneous dieting. Psychol Med, 25 (5), 1003-1010. DOI: 10.1017/s0033291700037491.

Green, M.W., Rogers, P.J. (1998). Impairments in working memory associated with spontaneous dieting behaviour. Psychol Med, 2 (5), 1063-1070. DOI: 10.1017/s0033291798007016. 
Green, M.W., Rogers, P.J., Elliman, N.A., Gatenby, S.J. (1994). Impairment of cognitive performance associated with dieting and high levels of dietary restraint. Physiol Behav, 55 (3), 447-452. DOI: 10.1016/0031-9384(94)90099-x.

Gupta, C.C., Centofanti, S., Dorrian, J., Coates, A., Stepien, J.M., Kennaway, D., Wittert, G., Heilbronn, L., Catcheside, P., Noakes, M., Coro, D., Chandrakumar, D., Banks, S. (2019). Altering meal timing to improve cognitive performance during simulated nightshifts. Chronobiol Int, 36 (12), 1691--1713. DOI: 10.1080/07420528.2019.1676256.

Gupta, C.C., Dorrian, J., Grant, C.L., Pajcin, M., Coates, A.M., Kennaway, D.J., Wittert, G.A., Heilbronn, L.K., Della Vedova, C.B., Banks, S. (2017). It's not just what you eat but when: The impact of eating a meal during simulated shift work on driving performance. Chronobiol Int, 34 (1), 66-77. DOI: 10.1080/07420528.2016.1237520.

Hagger, M.S., Chatzisarantis, N.L. (2013). The sweet taste of success: the presence of glucose in the oral cavity moderates the depletion of self-control resources. Pers Soc Psychol Bull, 39 (1), 28-42. DOI: 10.1177/0146167212459912.

Haier, R.J., Siegel, B., Tang, C., Abel, L., Buchsbaum, M.S. (1992). Intelligence and changes in regional cerebral glucose metabolic rate following learning. Intelligence, 16 (3), 415-426. DOI: 10.1016/0160-2896(92)90018-M.

Haier, R.J., Siegel, B.V., Jr., MacLachlan, A., Soderling, E., Lottenberg, S., Buchsbaum, M.S. (1992). Regional glucose metabolic changes after learning a complex visuospatial/motor task: a positron emission tomographic study. Brain Res, 570 (1-2), $134-143$. DOI: 10.1016/0006-8993(92)90573-r.

Hallmann, K., Giel, T. (2018). eSports - Competitive sports or recreational activity? Sport Management Review, 21 (1), 14-20. DOI: 10.1016/j.smr.2017.07.011.

Hamari, J., Sjöblom, M. (2017). What is eSports and why do people watch it? Internet research, 27 (2), 211-232.

Han, D.H., Lyoo, I.K., Renshaw, P.F. (2012). Differential regional gray matter volumes in patients with on-line game addiction and professional gamers. Journal of psychiatric research, 46 (4), 507-515. DOI: 10.1016/j.jpsychires.2012.01.004.

Hardy, L.L., Bell, J., Bauman, A., Mihrshahi, S. (2018). Association between adolescents' consumption of total and different types of sugar-sweetened beverages with oral health impacts and weight status. Aust N Z J Public Health, 42 (1), 22-26. DOI: 10.1111/1753-6405.12749.

Haskell-Ramsay, C.F., Jackson, P.A., Forster, J.S., Dodd, F.L., Bowerbank, S.L., Kennedy, D.O. (2018). The Acute Effects of Caffeinated Black Coffee on Cognition and Mood in Healthy Young and Older Adults. Nutrients, 10 (10). DOI: 10.3390/nu10101386.

Herculano-Houzel, S. (2011). Scaling of brain metabolism with a fixed energy budget per neuron: implications for neuronal activity, plasticity and evolution. PLoS One, 6 (3), e17514-e17514. DOI: 10.1371/journal.pone.0017514.

Himmelstein, D., Liu, Y., Shapiro, J. L. (2017). An exploration of mental skills among competitive league of legend players. International Journal of Gaming and Computer-Mediated Simulations (IJGCMS), 9 (2), 1-21.

Hoyland, A., Lawton, C.L., Dye, L. (2008). Acute effects of macronutrient manipulations on cognitive test performance in healthy young adults: a systematic research review. Neurosci Biobehav Rev, 32 (1), 72-85. DOI: 10.1016/j.neubiorev.2007.05.006.

Huang, J., Yan, E., Cheung, G., Nagappan, N., Zimmermann, T. (2017). Master Maker: Understanding Gaming Skill Through Practice and Habit From Gameplay Behavior. Topics in Cognitive Science, 9 (2), 437-466. DOI: 10.1111/tops.12251.

Isaac, V., Sim, S., Zheng, H., Zagorodnov, V., Tai, E.S., Chee, M. (2011). Adverse Associations between Visceral Adiposity, Brain Structure, and Cognitive Performance in Healthy Elderly. Frontiers in aging neuroscience, 3, 12-12. DOI: 10.3389/fnagi.2011.00012.

Jakobsen, L.H., Kondrup, J., Zellner, M., Tetens, I., Roth, E. (2011). Effect of a high protein meat diet on muscle and cognitive functions: a randomised controlled dietary intervention trial in healthy men. Clin Nutr, 30 (3), 303-311. DOI: 10.1016/j.clnu.2010.12.010.

Jones, E.K., Sunram-Lea, S.I., Wesnes, K.A. (2012). Acute ingestion of different macronutrients differentially enhances aspects of memory and attention in healthy young adults. Biol Psychol, 89 (2), 477-486. DOI: 10.1016/j.biopsycho.2011.12.017.

Jones, N.P., Siegle, G.J., Muelly, E.R., Haggerty, A., Ghinassi, F. (2010). Poor performance on cognitive tasks in depression: Doing too much or not enough? Cognitive, affective \& behavioral neuroscience, 10 (1), 129-140. DOI: 10.3758/CABN.10.1.129.

Kaur, N., Chugh, V., Gupta, A.K. (2014). Essential fatty acids as functional components of foods- a review. Journal of food science and technology, 51 (10), 2289-2303. DOI: 10.1007/s13197-012-0677-0.

Kemps, E., Tiggemann, M. (2005). Working memory performance and preoccupying thoughts in female dieters: evidence for a selective central executive impairment. Br J Clin Psychol, 44 (Pt 3), 357-366. DOI: 10.1348/014466505x35272.

Kemps, E., Tiggemann, M., Marshall, K. (2005). Relationship between dieting to lose weight and the functioning of the central executive. Appetite, 45 (3), 287-294. DOI: 10.1016/j.appet.2005.07.002.

Kempton, M.J., Ettinger, U., Foster, R., Williams, S.C., Calvert, G.A., Hampshire, A., Zelaya, F.O., O'Gorman, R.L., McMorris, T., Owen AMSmith, M.S. (2011). Dehydration affects brain structure and function in healthy adolescents. Hum Brain Mapp, 32 (1), 71-79. DOI: 10.1002/hbm.20999. 
Kennedy, D.O., Stevenson, E.J., Jackson, P.A., Dunn, S., Wishart, K., Bieri, G., Barella, L., Carne, A., Dodd, F.L., Robertson, B.C., Forster, J., Haskell-Ramsay, C.F. (2016). Multivitamins and minerals modulate whole-body energy metabolism and cerebral blood-flow during cognitive task performance: a double-blind, randomised, placebo-controlled trial. Nutrition \& metabolism, 13, 11-11. DOI: 10.1186/s12986-016-0071-4.

Kenney, E.L., Long, M.W., Cradock, A.L., Gortmaker, S.L. (2015). Prevalence of Inadequate Hydration Among US Children and Disparities by Gender and Race/Ethnicity: National Health and Nutrition Examination Survey, 2009-2012. Am J Public Health, 105 (8), e113-118. DOI: 10.2105/ajph.2015.302572.

Kerksick, C.M., Wilborn, C.D., Roberts, M. D., Smith-Ryan, A., Kleiner, S. M., Jager, R., .., Kreider, R.B. (2018). ISSN exercise \& sports nutrition review update: research \& recommendations. J Int Soc Sports Nutr, 15 (1), 38. DOI: 10.1186/s12970-018-0242-y.

Kim, J.Y., Kang, S.W. (2017). Relationships between Dietary Intake and Cognitive Function in Healthy Korean Children and Adolescents. Journal of lifestyle medicine, 7 (1), 10-17. DOI: 10.15280/jlm.2017.7.1.10.

Kokkinakis, A.V., Cowling, P.I., Drachen, A., Wade, A.R. (2017). Exploring the relationship between video game expertise and fluid intelligence. PLoS One, 12 (11), e0186621. DOI: 10.1371/journal.pone.0186621.

Kretchmer, N., Beard, J.L., Carlson, S. (1996). The role of nutrition in the development of normal cognition. Am J Clin Nutr, 63 (6), 997s-1001s. DOI: 10.1093/ajcn/63.6.997.

Kretsch, M.J., Green, M.W., Fong, A.K., Elliman, N.A., Johnson, H.L. (1997). Cognitive effects of a long-term weight reducing diet. Int J Obes Relat Metab Disord, 21 (1), 14-21. DOI: 10.1038/sj.ijo.0800353.

Landers, D.M., Arent, S.M., Lutz, R.S. (2001). Affect and Cognitive Performance in High School Wrestlers Undergoing Rapid Weight Loss. J Sport Exerc Psychol, 23 (4), 307-316. DOI: 10.1123/jsep.23.4.307.

Lange, F., Seer, C., Rapior, M., Rose, J., Eggert, F. (2014). Turn it all you want: Still no effect of sugar consumption on ego depletion. Journal of European Psychology Students, 5 (3).

Leigh Gibson, E., Green, M.W. (2002). Nutritional influences on cognitive function: mechanisms of susceptibility. Nutr Res Rev, 15 (1), 169-206. DOI: 10.1079/nrr200131.

Liang, J., Matheson, B.E., Kaye, W.H., Boutelle, K.N. (2014). Neurocognitive correlates of obesity and obesity-related behaviors in children and adolescents. Int J Obes (Lond), 38 (4), 494-506. DOI: 10.1038/ijo.2013.142.

Lieberman, H. (1999). The Role of Protein and Amino Acids in Sustaining and Enhancing Performance. Institute of Medicine: Washington, DC, USA.

Lim, W.S., Gammack, J.K., Van Niekerk, J., Dangour, A.D. (2006). Omega 3 fatty acid for the prevention of dementia. Cochrane Database Syst Rev (1), Cd005379. DOI: 10.1002/14651858.CD005379.pub2.

Lloyd, H.M., Green, M.W., Rogers, P.J. (1994). Mood and cognitive performance effects of isocaloric lunches differing in fat and carbohydrate content. Physiol Behav, 56 (1), 51-57. DOI: 10.1016/0031-9384(94)90260-7.

Lozoff, B., Beard, J., Connor, J., Barbara, F., Georgieff, M., Schallert, T. (2006). Long-lasting neural and behavioral effects of iron deficiency in infancy. Nutrition reviews, 64 (5 Pt 2), S34-S91. DOI: 10.1301/nr.2006.may.s34-s43.

Lupton, J.R., Brooks, J., Butte, N., Caballero, B., Flatt, J., Fried, S. (2005). Dietary reference intakes for energy, carbohydrate, fiber, fat, fatty acids, cholesterol, protein, and amino acids. National Academy Press: Washington, DC, USA, 265-337. DOI: 10.17226/10490.

Madsen, P.L., Hasselbalch, S.G., Hagemann, L.P., Olsen, K.S., Bulow, J., Holm, S., Wildschiødtz G., Paulson, O.B., Lassen, N.A. (1995). Persistent resetting of the cerebral oxygen/glucose uptake ratio by brain activation: evidence obtained with the KetySchmidt technique. J Cereb Blood Flow Metab, 15 (3), 485-491. DOI: 10.1038/jcbfm.1995.60.

Madzharov, A., Ye, N., Morrin, M., Block, L. (2018). The impact of coffee-like scent on expectations and performance. Journal of Environmental Psychology, 57, 83-86. DOI: 10.1016/j.jenvp.2018.04.001.

Majumdar, S., Chaudhuri, A., Ghar, M., Rahaman, W., Hai, A. (2017). Effect of obesity on nerve conduction study in an urban population of a developing country. Saudi Journal of Sports Medicine, 17 (3), 162-167. DOI: 10.4103/sjsm.sjsm_8_17.

Malik, V.S., Pan, A., Willett, W.C., Hu, F.B. (2013). Sugar-sweetened beverages and weight gain in children and adults: a systematic review and meta-analysis. The American journal of clinical nutrition, 98 (4), 1084-1102. DOI: 10.3945/ajcn.113.058362.

Martin, C.K., Anton, S.D., Han, H., York-Crowe, E., Redman, L.M., Ravussin, E., Williamson, D.A. (2007). Examination of cognitive function during six months of calorie restriction: results of a randomized controlled trial. Rejuvenation research, 10 (2), 179-190. DOI: 10.1089/rej.2006.0502.

Masento, N.A., Golightly, M., Field, D.T., Butler, L.T., van Reekum, C.M. (2014). Effects of hydration status on cognitive performance and mood. Br J Nutr, 111 (10), 1841-1852. DOI: 10.1017/s0007114513004455. 
McLellan, T.M., Caldwell, J.A., Lieberman, H.R. (2016). A review of caffeine's effects on cognitive, physical and occupational performance. Neurosci Biobehav Rev, 71, 294-312. DOI: 10.1016/j.neubiorev.2016.09.001.

Medic, N., Ziauddeen, H., Ersche, K.D., Faroogi, I.S., Bullmore, E.T., Nathan, P.J., Ronan L., Fletcher, P.C. (2016). Increased body mass index is associated with specific regional alterations in brain structure. Int J Obes (Lond), 40 (7), 1177-1182. DOI: 10.1038/ ijo.2016.42.

Messerotti Benvenuti, S., Zanatta, P., Valfre, C., Polesel, E., Palomba, D. (2012). Preliminary evidence for reduced preoperative cerebral blood flow velocity as a risk factor for cognitive decline three months after cardiac surgery: an extension study. Perfusion, 27 (6), 486-492. DOI: 10.1177/0267659112453475.

Messier, C. (2004). Glucose improvement of memory: a review. Eur J Pharmacol, 490 (1-3), 33-57. DOI: 10.1016/j.ejphar.2004.02.043.

Montero, D., Walther, G., Perez-Martin, A., Roche, E., Vinet, A. (2012). Endothelial dysfunction, inflammation, and oxidative stress in obese children and adolescents: markers and effect of lifestyle intervention. Obes Rev, 13 (5), 441-455. DOI: 10.1111/j.1467-789X.2011.00956.X.

Morris, A.A. (2005). Cerebral ketone body metabolism. J Inherit Metab Dis, 28 (2), 109-121. DOI: 10.1007/s10545-005-5518-0.

Morris, M.J., Beilharz, J.E., Maniam, J., Reichelt, A.C., Westbrook, R.F. (2015). Why is obesity such a problem in the 21 st century? The intersection of palatable food, cues and reward pathways, stress, and cognition. Neurosci Biobehav Rev, 58, 36-45. DOl: 10.1016/j.neubiorev.2014.12.002.

Mozaffarian, D., Aro, A., Willett, W.C. (2009). Health effects of trans-fatty acids: experimental and observational evidence. European Journal of Clinical Nutrition, 63 (2), S5-S21. DOI: 10.1038/sj.ejcn.1602973.

Murray, B., Rosenbloom, C. (2018). Fundamentals of glycogen metabolism for coaches and athletes. Nutr Rev, 76 (4), 243-259. DOI: 10.1093/nutrit/nuy001.

Olivo, G., Gaudio, S., Schiöth, H.B. (2019). Brain and Cognitive Development in Adolescents with Anorexia Nervosa: A Systematic Review of fMRI Studies. Nutrients, 11 (8), 1907. DOI: 10.3390/nu11081907.

Pendergast, F.J., Livingstone, K.M., Worsley, A., McNaughton, S.A. (2016). Correlates of meal skipping in young adults: a systematic review. The international journal of behavioral nutrition and physical activity, 13 (1), 125-125. DOI: 10.1186/s12966-016-0451-1.

Pereira, A.M., Brito, J., Figueiredo, P., Verhagen, E. (2019). Virtual sports deserve real sports medical attention. BMJ Open Sport \& Exercise Medicine, 5 (1), e000606-e000606. DOI: 10.1136/bmjsem-2019-000606.

Phillimore, P., Cox, B.D., Blaxter, M., Buckle, A.J.L. (1988). The Health and Lifestyle Survey, Health Promotion Research Trust, London, 1987. 212 pp. paper £15.00. Journal of Social Policy, 17 (4), 562-564. DOI: $10.1017 /$ S0047279400017141.

Pistell, P.J., Morrison, C.D., Gupta, S., Knight, A.G., Keller, J.N., Ingram, D.K., Bruce-Keller, A.J. (2010). Cognitive impairment following high fat diet consumption is associated with brain inflammation. J Neuroimmunol, 219 (1-2), 25-32. DOI: 10.1016/j. jneuroim.2009.11.010.

Prasad, C., Lieberman, H.R., Kanarek, R.B. (2005). Nutritional neuroscience: CRC Press.

Pross, N., Demazieres, A., Girard, N., Barnouin, R., Santoro, F., Chevillotte, Klein, A., Le Bellego, L. (2013). Influence of progressive fluid restriction on mood and physiological markers of dehydration in women. Br J Nutr, 109 (2), 313-321. DOI: 10.1017/ s0007114512001080.

Radd-Vagenas, S., Duffy, S.L., Naismith, S.L., Brew, B.J., Flood, V.M., Fiatarone Singh, M.A. (2018). Effect of the Mediterranean diet on cognition and brain morphology and function: a systematic review of randomized controlled trials. Am J Clin Nutr, 107 (3), 389-404. DOI: 10.1093/ajcn/nqx070.

Rampersaud, G.C., Pereira, M.A., Girard, B.L., Adams, J., Metzl, J.D. (2005). Breakfast habits, nutritional status, body weight, and academic performance in children and adolescents. J Am Diet Assoc, 105 (5), 743-760; quiz 761-742. DOI: 10.1016/j. jada.2005.02.007.

Reeves, S., Brown, B., Laurier, E. (2009). Experts at Play: Understanding Skilled Expertise. Games and Culture, 4 (3), 205-227. DOl: $10.1177 / 1555412009339730$.

Reichelt, A.C., Westbrook, R.F., Morris, M.J. (2017). Editorial: Impact of Diet on Learning, Memory and Cognition. Frontiers in behavioral neuroscience, 11, 96-96. DOI: 10.3389/fnbeh.2017.00096.

Reyner, L.A., Wells, S.J., Mortlock, V. Horne, J.A. (2012). 'Post-lunch' sleepiness during prolonged, monotonous driving - effects of meal size. Physiol Behav, 105 (4), 1088-1091. DOI: 10.1016/j.physbeh.2011.11.025.

Riby, L.M. (2004). The Impact of Age and Task Domain on Cognitive Performance: A Meta-Analytic Review of the Glucose Facilitation Effect. Brain Impairment, 5 (2), 145-165. DOI: 10.1375/brim.5.2.145.58253. 
Riebl, S.K., Davy, B.M. (2013). The Hydration Equation: Update on Water Balance and Cognitive Performance. ACSM's health \& fitness journal, 17 (6), 21-28. DOI: 10.1249/FIT.0b013e3182a9570f.

Robinson, J.G., ljioma, N., Harris, W. (2010). Omega-3 fatty acids and cognitive function in women. Womens Health (Lond), 6 (1), 119-134. DOI: 10.2217/whe.09.75.

Rogers, P.J., Kainth, A., Smit, H.J. (2001). A drink of water can improve or impair mental performance depending on small differences in thirst. Appetite, 36 (1), 57-58. DOI: 10.1006/appe.2000.0374.

Rothwell, G., Shaffer, M. (2019). eSports in K-12 and Post-Secondary Schools. Education Sciences, 9 (2), 105. Retrieved from https:/l www.mdpi.com/2227-7102/9/2/105.

Rudolf, K., Bickmann, P., Froböse, I., Tholl, C., Wechsler, K. Grieben, C. (2020). Demographics and Health Behavior of Video Game and eSports Players in Germany: The eSports Study 2019. International journal of environmental research and public health, 17 (6), 1870. DOI: 10.3390/ijerph17061870.

Sastry, P.S. (1985). Lipids of nervous tissue: composition and metabolism. Prog Lipid Res, 24 (2), 69-176. DOI: 10.1016/0163-7827(85)90011-6.

Scholey, A.B., Harper, S., Kennedy, D.O. (2001). Cognitive demand and blood glucose. Physiol Behav, 73 (4), 585-592. DOI: 10.1016/ s0031-9384(01)00476-0.

Scholey, A.B., Laing, S., Kennedy, D.O. (2006). Blood glucose changes and memory: effects of manipulating emotionality and mental effort. Biol Psychol, 71 (1), 12-19. DOI: 10.1016/j.biopsycho.2005.02.003.

Schütz, M. (2016). Science shows that eSports professionals are real athletes. Retrieved from: https://www.dw.com/en/science-showsthat-esports-professionals-are-real-athletes/a-19084993 (22/01/2020).

Scott, S.P., Murray-Kolb, L.E. (2016). Iron Status Is Associated with Performance on Executive Functioning Tasks in Nonanemic Young Women. J Nutr, 146 (1), 30-37. DOI: 10.3945/jn.115.223586.

Sebastian, S.B., Williamson, D.A., Blouin, D.C. (1996). Memory bias for fatness stimuli in the eating disorders. Cognitive Therapy and Research, 20 (3), 275-286.

Shaw, J., Tiggemann, M. (2004). Dieting and working memory: preoccupying cognitions and the role of the articulatory control process. Br J Health Psychol, 9 (Pt 2), 175-185. DOI: 10.1348/135910704773891032.

Siervo, M., Arnold, R., Wells, J.C.K., Tagliabue, A., Colantuoni, A., Albanese, E., ..., Stephan, B.C.M. (2011). Intentional weight loss in overweight and obese individuals and cognitive function: a systematic review and meta-analysis. Obesity Reviews, 12 (11), 968-983. DOI: 10.1111/j.1467-789X.2011.00903.x.

Sihvola, N., Korpela, R., Henelius, A., Holm, A., Huotilainen, M., Muller, K., ..., Peuhkuri, K. (2013). Breakfast high in whey protein or carbohydrates improves coping with workload in healthy subjects. Br J Nutr, 11 (9), 1712-1721. DOI: 10.1017/s0007114513000779

Smeets, J.S.J., Horstman, A.M.H., Schijns, O.E.M.G., Dings, J.T.A., Hoogland, G., Gijsen, A.P., ..., van Loon, L.J.C. (2018). Brain tissue plasticity: protein synthesis rates of the human brain. Brain, 141 (4), 1122-1129. DOI: 10.1093/brain/awy015.

Smith, A., Maben, A., Brockman, P. (1994). Effects of evening meals and caffeine on cognitive performance, mood and cardiovascular functioning. Appetite, 22 (1), 57-65. DOI: 10.1006/appe.1994.1005.

Smith, A.P., Clark,R., Gallagher, J. (1999). Breakfast cereal and caffeinated coffee: effects on working memory, attention, mood, and cardiovascular function. Physiol Behav, 67 (1), 9-17. DOI: 10.1016/s0031-9384(99)00025-6.

Smith, A.P., Miles, C. (1986). The effects of lunch on cognitive vigilance tasks. Ergonomics, 29 (10), 1251-1261. DOI: 10.1080/ 00140138608967238.

Smith, M.A., Riby, L.M., Eekelen, J.A., Foster, J.K. (2011). Glucose enhancement of human memory: a comprehensive research review of the glucose memory facilitation effect. Neurosci Biobehav Rev, 35 (3), 770-783. DOI: 10.1016/j.neubiorev.2010.09.008.

Stanek, K.M., Grieve, S.M., Brickman, A.M., Korgaonkar, M.S., Paul, R.H., Cohen, R.A., Gunstad, J.J. (2011). Obesity is associated with reduced white matter integrity in otherwise healthy adults. Obesity (Silver Spring), 19 (3), 500-504. DOI: 10.1038/oby.2010.312.

Statovci, D., Aguilera, M., MacSharry, J., Melgar, S. (2017). The Impact of Western Diet and Nutrients on the Microbiota and Immune Response at Mucosal Interfaces. Frontiers in immunology, 8, 838-838. DOI: 10.3389/fimmu.2017.00838.

Stender, S., Astrup, A., Dyerberg, J. (2008). Ruminant and industrially produced trans fatty acids: health aspects. Food Nutr Res, 52. DOI: 10.3402/fnr.v52i0.1651.

Stern, Y. (2017). An approach to studying the neural correlates of reserve. Brain Imaging Behav, 11 (2), 410-416. DOI: 10.1007I s11682-016-9566-x.

Stookey, J.D. (2005). High prevalence of plasma hypertonicity among community-dwelling older adults: results from NHANES III. J Am Diet Assoc, 105 (8), 1231-1239. DOI: 10.1016/j.jada.2005.05.003. 
Sweat, V., Yates, K.F., Migliaccio, R., Convit, A. (2017). Obese Adolescents Show Reduced Cognitive Processing Speed Compared with Healthy Weight Peers. Child Obes, 13 (3), 190-196. DOI: 10.1089/chi.2016.0255.

Tanaka, H., Taira, K., Arakawa, M., Masuda, A., Yamamoto, Y., Komoda, Y., ..., Shirakawa, S. (2002). An examination of sleep health, lifestyle and mental health in junior high school students. Psychiatry Clin Neurosci, 56 (3), 235-236. DOI: 10.1046/j.1440-1819.2002.00997.x.

Taylor, N., Elam, J. (2018). 'People are robots, too': Expert gaming as autoplay. Journal of Gaming and Virtual Worlds, 10 (3), 243-260. DOI: 10.1386/jgvw.10.3.243_1

Thomas, C.J., Rothschild, J., Earnest, C.P., Blaisdell, A. (2019). The Effects of Energy Drink Consumption on Cognitive and Physical Performance in Elite League of Legends Players. Sports (Basel), 7 (9). DOI: 10.3390/sports7090196.

Tomey, K.M., Sowers, M R., Li, X., McConnell, D.S., Crawford, S., Gold, E.B., ..., Randolph, J.F., Jr. (2007). Dietary fat subgroups, zinc, and vegetable components are related to urine F2a-isoprostane concentration, a measure of oxidative stress, in midlife women. J Nutr, 137 (11), 2412-2419. DOI: 10.1093/jn/137.11.2412.

Trumbo, P., Yates, A.A., Schlicker, S., Poos, M. (2001). Dietary reference intakes: vitamin A, vitamin K, arsenic, boron, chromium, copper, iodine, iron, manganese, molybdenum, nickel, silicon, vanadium, and zinc. Journal of the Academy of Nutrition and Dietetics, 101 (3), 294.

van de Rest, O., van der Zwaluw, N.L., de Groot, L.C. (2013). Literature review on the role of dietary protein and amino acids in cognitive functioning and cognitive decline. Amino Acids, 45 (5), 1035-1045. DOI: 10.1007/s00726-013-1583-0.

van Exel, E., de Craen, A.J., Remarque, E.J., Gussekloo, J., Houx, P., Bootsma-van der Wiel, A., ..., Westendorp, R.G. (2003). Interaction of atherosclerosis and inflammation in elderly subjects with poor cognitive function. Neurology, 61 (12), 1695-1701. DOI: 10.1212/01.wnl.0000098877.07653.7c.

Veronese, N., Facchini, S., Stubbs, B., Luchini, C., Solmi, M., Manzato, E., ..., Fontana, L. (2017). Weight loss is associated with improvements in cognitive function among overweight and obese people: A systematic review and meta-analysis. Neurosci Biobehav Rev, 72, 87-94. DOI: 10.1016/j.neubiorev.2016.11.017.

Vreugdenburg, L., Bryan, J., Kemps, E. (2003). The effect of self-initiated weight-loss dieting on working memory: the role of preoccupying cognitions. Appetite, 41 (3), 291-300. DOI: 10.1016/s0195-6663(03)00107-7.

Wasserman, D.H. (2009). Four grams of glucose. Am J Physiol Endocrinol Metab, 296 (1), E11-21. DOI: 10.1152/ajpendo.90563.2008.

Wright, R.S., Gerassimakis, C., Bygrave, D., Waldstein, S.R. (2017). Dietary Factors and Cognitive Function in Poor Urban Settings. Current nutrition reports, 6 (1), 32-40. DOI: 10.1007/s13668-017-0186-X.

Xu, J., Li, Y., Lin, H., Sinha, R., Potenza, M.N. (2013). Body mass index correlates negatively with white matter integrity in the fornix and corpus callosum: a diffusion tensor imaging study. Hum Brain Mapp, 34 (5), 1044-1052. DOI: 10.1002/hbm.21491.

Yau, P.L., Kang, E.H., Javier, D.C., Convit, A. (2014). Preliminary evidence of cognitive and brain abnormalities in uncomplicated adolescent obesity. Obesity (Silver Spring, Md.), 22 (8), 1865-1871. DOI: 10.1002/oby.20801.

Yeomans, M.R. (2017). Adverse effects of consuming high fat-sugar diets on cognition: implications for understanding obesity. Proc Nutr Soc, 76 (4), 455-465. DOI: 10.1017/s0029665117000805.

Zhang, N., Du, S.M., Zhang, J.F., Ma, G.S. (2019). Effects of Dehydration and Rehydration on Cognitive Performance and Mood among Male College Students in Cangzhou, China: A Self-Controlled Trial. International journal of environmental research and public health, 16 (11). DOI: 10.3390/ijerph16111891.

Zimmermann, M.B. (2009). Iodine deficiency. Endocr Rev, 30 (4), 376-408. DOI: 10.1210/er.2009-0011.

Cite this article aS: Ribeiro, F.J., Viana, V.M., Borges, N.P., Teixeira, V.H. (2021). The Emergence of eSports Nutrition: A Review. Central European Journal of Sport Sciences and Medicine, 1 (33), 81-95. DOI: 10.18276/cej.2021.1-08. 